\title{
DIRECTIONS FOR ENSURING THE EQUIVALENCE OF EXCHANGE IN AGRI-FOOD CHAINS IN UKRAINE
}

\author{
Olha.0. Varchenko* \\ Bila Tserkva National Agrarian University, Ukraine
}

\begin{abstract}
The article examines the issues of intersectoral price relations in agri-food chains in Ukraine. It is proved that the imbalance of relations between different spheres of the agro-industrial complex due to price disparity causes the withdrawal of financial resources from one industry to another, without creating conditions for expanded reproduction. The factors influencing prices in agri-food chains are systematized: inflation, disparity, currency fluctuations, sales channels, etc. It is confirmed that the subjects of entrepreneurial activity of the agricultural sector of economy operated in conditions of price disparity during 2000-2019, which led to a relatively low value of their profitability. At the level of a participant in the chain of food industry entities, the price index for food industry products has been exceeded over the agricultural level, but there is a very low level of profitability $-1.4 \%$ in 2019 . Analytically proved existence of a disparity between retail prices for food and agricultural products provides a profitability of wholesale and retail trade at $15.8-23.3 \%$. Violation of the equivalence of exchange in supply chains at the level of wholesale and retail trade leads to the entry of agricultural enterprises into vertically integrated associations of the holding type. It is substantiated that ensuring the equivalence of exchange in agri-food chains requires the introduction of a set of value-added tools in the agricultural sector of antitrust regulation, market infrastructure development, rural cooperation and integration, and support for the development of small producers.
\end{abstract}

Keywords: agri-food chain, added value, price parity, gross value added

\section{Introduction}

The formation of a system of economic relations, the conduct of radical socio-economic transformations in Ukraine determine the new qualitative characteristics of intersectoral relations in the agri-industrial sector of the country. It should be noted that the development of agri-food chains is characterized by various forms and methods of relations between economic entities in the process of trade from producer to final consumer and has a significant impact on their final financial results and the economic development of Ukraine.

The analysis of the state of the agri-food complex of the country in the period of market transformations and the formation of diversified economy shows that a sharp decline in total production at the initial stage of reform was largely due to disruption of intersectoral ties at national, regional and domestic levels. Disintegration processes have led to the formation of unbalanced reproductive structure of the complex, hypertrophied share of agricultural production in general indicators of its development, low efficiency of resource use, weakening of intersectoral flows and increase in internal turnover, degradation of material and technical base, and reduced efficiency of functioning.

The positive changes in the macroeconomic situation of the country, which have been observed in recent years, create the preconditions for economic growth of agri-industrial production, which allows to intensify structural adjustment. However, the prospects for further development of the agri-food complex largely depend on the choice of effective mechanisms for intersectoral relations that take into account the interests of producers in food chains and priorities in forming intersectoral proportions that reflect the structural policy of the state; development of new strategies for the development of the agri-food complex as a holistic system focused on solving the problems of food security of the country, increasing living standards, increasing the competitiveness of domestic producers in the domestic and world food markets.

\section{Materials and methods}

The study of the peculiarities of value formation in agri-food chains must be carried out within the concept of value chain, which takes into account the activities of all its actors (participants) to bring agri-food from producer to end consumer (Pomarici, 2018). The information base of the study was the data of the State Statistics Service of Ukraine, in particular the table "Costs Output", which shows the formation of gross domestic product in the country as a whole and in terms of individual institutional sectors and economic activities, as well as its main components: intermediate consumption and gross value added. Economic transactions in the system of national accounts are accounted for at actual prices in effect at the time of the transaction, using the accrual method. At basic prices (consumer prices excluding taxes and subsidies) output and gross value added at the level of institutional sectors and types of economic activity are calculated, at market prices - output for the economy as a whole and GDP.

In order to neutralize the impact of the price component and obtain an objective value of changes in real production volumes, gross value added, done the reduction of economic indicators, calculated in current (market) prices, to constant prices for a set of goods and services. In conducting the study, we used the GDP deflator at 2000 prices.

When determining the calculation of the price parity index, we used the method of the simple parity index, which is defined as the ratio of two price indices, and when calculating the indices of price changes for the output of each member of the agri-food chain we used the accumulation method. The base year was 2000 , which is characterized as the most economically stable one.

\section{Result and discussion}

It is known that ensuring the balanced development of the agri-food system is achieved on the basis of rational intersectoral relations, which is based on the principle of equivalent intersectoral exchange, positive dynamics of those 
elements that form the main increase in value added, including agricultural and food prices.

The problem of ensuring price balance, equivalence of intersectoral exchange is becoming more acute as the development of structural relationships of the agri-food complex, expanding its scale, and intersectoral relations with other intersectoral complexes and industries (Vasylenka, 2013). According to the results of empirical calculations, price liberalization deepens the price disparity between industries. Thus, price parity, as it provides for equal proportions in the exchange between industries and spheres of production, allows creation of equally profitable level of profitability with equal efficiency of management. Note that price parity is influenced by many factors - the degree of export orientation of the agricultural sector of the economy, the structure of agricultural production, the peculiarities of the institutional structure.

Currently, the process of price formation at all stages of the movement of agricultural products from producer to final consumer in the country is in accordance with the laws of market economy. Starting from June 7, 2017, the Resolution of the Cabinet of Ministers of Ukraine № 394 “ On Amendments to the Resolution of the Cabinet of Ministers of Ukraine of December 25, 1996 no. 1548 and Repeal of Certain Resolutions of the Cabinet of Ministers of Ukraine" repealing state regulation prices for food products and services in the markets.

In particular, from July 1, 2017, state regulation of prices for food products and services were abolished in terms of establishing: trade surcharges not exceeding $15 \%$ to the wholesale price of the producer (customs value) for 15 groups of goods (flour, bread, pasta, cereals, sugar, beef, pork and poultry, boiled sausages, milk, cheese, sour cream, butter butter, sunflower oil, chicken eggs); declaration of changes in wholesale prices for 13 groups of goods (wheat flour of the highest, first and second grade, rye flour, buckwheat, beef, pork, poultry (carcass), cooked sausages, except premium, cow's milk') drinking barley (pasteurized, packed in film), sour milk cheese with a fat content of up to $9 \%$, sour cream with a fat content of up to $20 \%$, butter with a fat content of up to $72.5 \%$, chicken eggs, granulated sugar, sunflower oil); marginal levels of profitability of flour and bread production of social varieties; marginal levels of profitability and trade allowances for baby food; marginal levels of profitability of packaging (packaging) of food products, in respect of which state price regulation has been introduced, without taking into account the cost of raw materials not higher than 10\%; state regulation of prices for services in the markets for the sale of food and non-food products.

It should be noted that in March 2020, the Cabinet of Ministers established for the time of quarantine state regulation of prices by declaring the prices of 10 food products, including: buckwheat, sugar, premium wheat flour, pasta (vermicelli from premium flour), pasteurized milk in films with a fat content of $2.5 \%$, rye-wheat bread, eggs of category $\mathrm{C1}$, chicken carcass, mineral water without gas, butter with a fat content of $72.5 \%$. However, the envisaged instruments of state regulation did not have a significant impact on reducing the growth rate of prices for agricultural products and food in the country.

The results of the analysis of the data of the State Statistics Service of Ukraine allow us to conclude that during 2010-2018 there are different rates of change in prices for agricultural products, prices of processing enterprises and trade (Table 1). It is quite obvious that, provided that the equivalence of exchange is ensured, there should be no significant differences in the values of price indices throughout the agri-food chain (Hahren, 2018).

Thus, the imbalance of relations between different areas of the agriindustrial complex as a result of price disparity leads to the withdrawal of financial resources from one sector to another, thus not creating opportunities for expanded reproduction in agriculture, food industry, trade and posing certain threats to the functioning of agri-food chains of domestic products (Varchenko et al., 2018).

Analyzing the process of price formation at all stages of trade in agricultural products and food, we can state that inflationary expectations and the manifestation of destructive phenomena in the socio-political life of the country also have a significant impact, which reflects the impact of the superstructure on society.

Obviously, provided that the equivalence of exchange is observed, price fluctuations within the agri-food chain must be synchronous. At the same time, in domestic practice there are significant deviations of prices for the same type of product at the level of sales participants, which allow us to conclude about the significant impact on the formation of purchase prices in agri-food supply chains. Thus, agricultural enterprises sell the vast majority of their products to trade and intermediary structures, with the exception of milk and sugar beets, which are further sold in both domestic and foreign

Table 1 Dynamics of indices of purchase prices for agricultural products, producer prices of processing industry and retail trade prices (\%)

\begin{tabular}{|c|c|c|c|c|c|c|}
\hline \multirow[t]{3}{*}{ Year } & \multicolumn{3}{|c|}{ Price indices } & \multicolumn{3}{|c|}{ The ratio of indices in. $n .(+,-)$} \\
\hline & \multirow{2}{*}{ agriculture } & \multirow{2}{*}{ processing industry } & \multirow{2}{*}{ trade } & \multirow{2}{*}{$\begin{array}{c}\text { processing } \\
\text { industry/agriculture }\end{array}$} & \multicolumn{2}{|c|}{ trade to } \\
\hline & & & & & agriculture & processing industry \\
\hline 2010 & 130.0 & 118.7 & 110.6 & -11.3 & -19.4 & -8.1 \\
\hline 2011 & 113.6 & 114.2 & 101.7 & 0.6 & -11.9 & -12.5 \\
\hline 2012 & 106.8 & 100.3 & 97.7 & -6.5 & -9.1 & -2.6 \\
\hline 2013 & 97.1 & 101.7 & 99.3 & 4.6 & 2.2 & -2.4 \\
\hline 2014 & 124.3 & 102.1 & 124.8 & -22.2 & 0.5 & 22.7 \\
\hline 2015 & 154.5 & 99.8 & 141.5 & -54.7 & -13 & 41.7 \\
\hline 2016 & 109.0 & 102.9 & 103.3 & -6.1 & -5.7 & 0.4 \\
\hline 2017 & 111.5 & 101.2 & 117.7 & -10.3 & 6.2 & 16.5 \\
\hline 2019 & 92.4 & 99.2 & 104.8 & 6.8 & 12.4 & 5.6 \\
\hline
\end{tabular}

Source: calculated according to the State Statistics Service of Ukraine 
markets. Given the supply of agri-food products for export, fluctuations in product prices are significantly affected by the level of world prices for certain types of agricultural products and food, as well as currency fluctuations.

The specificity of domestic conditions is that there is a positive relationship between inflation and the intensity of structural changes: higher inflation was accompanied by more intense structural changes and vice versa (Hruzdiev, 2014).This effect is observed not only in the short term, but also in the long run, where it is clearly expressed. The presence of a long-term effect of the relationship of accumulated structural changes and total price growth is a specific development and a factor of intersectoral balance. The difference between financially strong and weak industries illustrates the dynamics of their share in the formation of value added in material production. Note that the economically weak sectors in developed countries include only agriculture (Aleinikova, 2011.).

It is known that inflation distorts all intersectoral price ratios. It is organically associated with the uneven growth of individual prices, and causes structural changes in price ratios. Non-compliance with equivalence, which is a violation of the laws of intersectoral exchange and trade, is one of the causes of intersectoral and reproductive imbalance.

The structural and non-monetary nature of inflation is one of the important limitations of structural transformations, ensuring intersectoral balance (Oliinyk, 2015). Unbalanced inflation is characterized by the fact that the prices of different goods are constantly changing in relation to each other, and in different proportions. Both in the sectoral and in the territorial context, unbalanced jumps in relative prices are observed. At the same time, the dynamics of prices is significantly influenced by the inertia of inflation and inflation expectations. It is believed that the condition for obtaining gross value added by agriculture, food industry, and trade is the relative parity of prices for input resources and final products (Oliinyk, 2015). Currently in Ukraine, price parity is determined in relation to 2000, which was the starting point for the agrarian reform and the most favourable period for the agricultural sector.

It is established that during 2000-2019, the subjects of entrepreneurial activity of the agricultural sector of the economy operated in conditions of price disparity, which provided a low level of profitability, which during 2010-2019 was $16.1-17.5 \%$, respectively. However, there is a decrease in the share of unprofitable agricultural enterprises from $30.2 \%$ in 2010 to $16.5 \%$ in 2019 (Table 2). Thus, the farms of the corporate sector ensure the effective functioning of measures to improve the efficiency of production and economic activities on the basis of innovation.

The calculations of Table 2 show that there is an excess of the price index for food products over agricultural. Such a situation creates conditions of inequality between participants in agri-food chains of agricultural products. This circumstance forces business entities in the field of agribusiness to sell their products to trade and intermediary structures, in which the level of procurement is higher than in processing enterprises.

Table 2 Price indices of sales of agricultural products, material and technical resources consumed by agriculture, food industry and retail trade and the value of their parity (\%)

\begin{tabular}{|c|c|c|c|c|c|c|c|c|}
\hline \multirow[t]{2}{*}{ Year } & \multicolumn{4}{|c|}{ sales price indices (accumulated since 2000) } & \multicolumn{4}{|c|}{ Price parity index } \\
\hline & $\begin{array}{l}\text { agricultural } \\
\text { products }\end{array}$ & $\begin{array}{l}\text { material and technical } \\
\text { resources consumed by } \\
\text { agriculture }\end{array}$ & $\begin{array}{l}\text { food industry } \\
\text { products }\end{array}$ & food products & $\begin{array}{l}\text { agricultural products/ } \\
\text { MTP consumed by } \\
\text { agriculture }\end{array}$ & $\begin{array}{l}\text { food industry/ } \\
\text { agricultural } \\
\text { products }\end{array}$ & $\begin{array}{l}\text { food products/ } \\
\text { food industry } \\
\text { products }\end{array}$ & $\begin{array}{l}\text { food/ } \\
\text { agricultural } \\
\text { products }\end{array}$ \\
\hline 2000 & 100 & 100 & 100 & 100 & & & & \\
\hline 2001 & 105 & 105.3 & 105 & 108 & 99.7 & 100 & 102.86 & 102.9 \\
\hline 2003 & 110.7 & 109.1 & 113.5 & 117.1 & 101.4 & 102.53 & 103.2 & 105.8 \\
\hline 2004 & 117 & 128.5 & 127.2 & 134.9 & 91 & 108.74 & 106.06 & 115.3 \\
\hline 2005 & 126.5 & 147.4 & 138.1 & 148.7 & 85.8 & 109.24 & 107.62 & 117.6 \\
\hline 2006 & 129.5 & 168.1 & 146.2 & 153.4 & 77 & 112.87 & 104.97 & 118.5 \\
\hline 2008 & 197.1 & 289.4 & 212.4 & 236.3 & 68.1 & 107.78 & 111.23 & 119.9 \\
\hline 2009 & 209.7 & 292.3 & 255.6 & 262 & 71.7 & 121.86 & 102.54 & 124.9 \\
\hline 2010 & 272.6 & 337.6 & 303.9 & 289.8 & 80.7 & 111.45 & 95.38 & 106.3 \\
\hline 2011 & 309.7 & 400.5 & 334.6 & 294.7 & 77.3 & 108.02 & 88.1 & 95.2 \\
\hline 2012 & 330.8 & 431.3 & 346.6 & 288 & 76.7 & 104.78 & 83.08 & 87.1 \\
\hline 2013 & 321.2 & 430 & 359.8 & 286 & 74.7 & 112.01 & 79.48 & 89 \\
\hline 2014 & 400.2 & 516 & 458 & 356.9 & 77.6 & 114.44 & 77.92 & 89.2 \\
\hline 2015 & 618.3 & 751.3 & 624.7 & 505 & 82.3 & 101.03 & 80.83 & 81.7 \\
\hline 2016 & 674 & 782.8 & 725.9 & 521.6 & 86.1 & 107.71 & 71.86 & 77.4 \\
\hline 2017 & 751.5 & 975.4 & 816.6 & 614 & 77 & 108.67 & 75.18 & 81.7 \\
\hline 2019 & 758.9 & 1112.4 & 889.5 & 693.6 & 68.2 & 117.21 & 77.98 & 91.4 \\
\hline
\end{tabular}

Source: calculated according to the State Statistics Service of Ukraine 
It is obvious that the imperfect development of trade and intermediary structures that perform the functions of distribution logistics in agri-food chains cause the manifestation of negative processes among agricultural producers, which can even lead to curtailment in the production programme of certain products. Thus, a similar phenomenon is observed in dairy farming where the vast majority of milk produced in the corporate sector is sold to processing enterprises. Milk production in 2019 in farms of all categories decreased by $3.7 \%$ to 9,687 thousand tons, and directly in agricultural enterprises produced $2,717.7$ thousand tons of milk, which is $1.4 \%$ less than from 2018. It should be noted that households (private farms) produced $6,969.2$ thousand tons of milk, which is 4.6 less than in the analyzed period of 2018.

At the same time, despite the favourable price ratio, the level of profitability of food industry enterprises in 2019 is only $1.4 \%$, which indicates a low level of efficiency of production and economic activities of processing enterprises. At the same time, despite the disparity between retail prices for food and agricultural products, there is a profitability of economic activity of wholesale and retail trade, which was 15.8-23.3\% during 2016-2018. This circumstance indicates favuorable conditions and the availability of internal reserves for the development of business entities in the field of wholesale and retail trade.

We believe that the equivalence of intersectoral relations for agriculture, food industry, and trade should be considered on the basis of the formed value of gross value added. The price ratio does not in itself determine such important aspects of the equivalence of relations as the levels of remuneration of workers in various industries, the possibility of expanded reproduction, etc. (Burkovskyi, 2014). Information on the values of intermediate consumption, gross value added and output is reflected in the system of national accounts. The change in the conditions for the formation of gross value added (GVA) in the system of national accounts can be traced on the basis of the GVA deflator by industry and the economy as a whole. To do this, it is necessary to compare the nominal and real sectoral structure of the formation of airborne troops. As a value component of the nominal gross domestic product and gross value added we use the comparative prices of 2000 . We believe that this methodological approach will provide an objective calculation of the equivalence of exchange and the amount of losses from its violation, and its testing will be carried out at the level of agriculture. The calculations show that during the study period there is an increase in gross value added in general in the sectors of the economy and agriculture in particular (Table 3). At the same time, there is a decrease in the share of GVA of agriculture in the structure of gross value added in the national economy as a whole.

At the same time, the calculated value of GVA in the general sectors of economy after the use of the GDP deflator based on prices in 2000, indicates a slightly different trend. This circumstance allows us to conclude that the subjective determination of gross value added at the macroeconomic level through the manifestation of inflation in the economy is allowed.

Analyzing the estimated data on gross value added in general for the national economy and agriculture, in particular, during 2000-2018, a relatively small increase in this indicator of economic development. In addition, there is an increase in the share of agriculture in the structure of gross value added as a whole in the national economy by 3.4 percentage points, and this industry occupies the largest share, both in the structure of GDP and GVA. Thus, we can conclude that the calculations confirm the current realities of the role and place of agriculture in economy.

Using the proposed method, we calculated the losses of agriculture from the inequality of intersectoral relations, the resulting indicator of which is the gross value added (Table 4). The result of intersectoral redistribution of income under the influence of changes in relative prices is calculated as the difference between value added actually obtained and that which could be obtained with a uniform increase in prices.

According to the results of research conducted during 2000-2018, there is an increase in the volume of unearned gross value added of business entities in the field of agriculture from the violation of the equivalence of intersectoral relations. Thus, despite significant financial investments in the form of state support, the negative trend of reducing the number of business entities in the field of agribusiness does not stop. Thus, during 2010-2019 the number of agricultural enterprises decreased by $15 \%$ and in the reporting year amounted to 48,504 business units.

Note that foreign researchers also argue that in all agricultural sectors, prices paid to farmers vary greatly depending on various factors, sales channels, product differentiation, management structure between the farmer and the buyer. In addition, the rules for determining profit margins applied by supermarkets and milk processors are not transparent. The more successfully farmers and processors can differentiate their products and persuade consumers to pay more, the higher their share of the price charged by retailers. At the same time, other problems, such as surplus production and

Table 3 Dynamics of gross value added in general on the national economy and agriculture in the basic prices of 2018 and 2000

\begin{tabular}{|c|c|c|c|c|c|c|c|}
\hline \multirow[t]{2}{*}{ Indicator } & \multicolumn{5}{|c|}{ Year } & \multicolumn{2}{|c|}{$2018(\%$ to $)$} \\
\hline & 2000 & 2005 & 2010 & 2017 & 2018 & 2000 & 2017 \\
\hline $\begin{array}{l}\text { GVA of the national economy in basic prices } \\
\text { (UAH million) }\end{array}$ & 150,320 & 404,474 & 954,472 & $2,519,561$ & $3,018,190$ & 20.07 times & 119 \\
\hline GVA of Agriculture (UAH million) & 24,573 & 40,589 & 80,385 & 303,949 & 361,173 & 14.69 times & 118 \\
\hline Share of GVA in agriculture (\%) & 16.3 & 10 & 8.4 & 12.1 & 12.0 & -4.3 in \% & $0.1 \mathrm{in} \%$ \\
\hline GVA deflator of agriculture up to 2000 (\%) & 100 & 179 & 416 & 1,160 & 1,338 & 1,238 in $\%$ & 178 in \% \\
\hline GVA deflator up to 2000 (\%) & 100 & 138 & 258 & 741 & 815 & 715 in \% & 74 in \% \\
\hline GVA in 2000 prices (UAH million) & 150,320 & 225,631 & 229,251 & 217,166 & 225,545 & 150 & 103 \\
\hline GVA of agriculture in 2000 prices (UAH million) & 24,573 & 29,397 & 31,187 & 41,032 & 44,331 & 180 & 108 \\
\hline Share of agriculture (\%) & 16.3 & 13.0 & 13.6 & 18.9 & 19.7 & $3.4 \mathrm{in} \%$ & $0.8 \mathrm{in} \%$ \\
\hline
\end{tabular}

Source: calculated according to the State Statistics Service of Ukraine 
Table 4 Calculation of losses of agriculture from inequality of intersectoral relations

\begin{tabular}{|c|c|c|c|c|c|}
\hline Year & $\begin{array}{l}\text { GDP in } 2000 \text { prices } \\
\text { (UAH million) }\end{array}$ & $\begin{array}{c}\text { Share of agriculture in current } \\
\text { prices (\%) }\end{array}$ & $\begin{array}{l}\text { GVA of agriculture in the } \\
\text { prices of } 2000 \text { (UAH million) }\end{array}$ & $\begin{array}{l}\text { GVA of agriculture in } 2000 \text { prices by structure } \\
\text { in current prices (UAH million) (revenues } \\
\text { received in comparable prices) }\end{array}$ & $\begin{array}{l}\text { Unearned GVA at the prices } \\
\text { of } 2000 \mathrm{mln} \text {. UAH }\end{array}$ \\
\hline 2000 & 150,320 & 16.3 & 24,573 & 24,573 & 0 \\
\hline 2001 & 170,026 & 15.7 & 27,035 & 26,767 & -268 \\
\hline 2002 & 180,140 & 14.1 & 27,552 & 25,371 & $-2,181$ \\
\hline 2003 & 198,693 & 11.6 & 24,489 & 23,123 & $-1,366$ \\
\hline 2004 & 224,492 & 11.5 & 29,315 & 25,739 & $-3,576$ \\
\hline 2005 & 225,631 & 10 & 29,397 & 22,642 & $-6,755$ \\
\hline 2006 & 240,801 & 8.3 & 29,885 & 19,898 & $-9,987$ \\
\hline 2007 & 261,665 & 7.1 & 28,040 & 18,564 & $-9,476$ \\
\hline 2008 & 267,000 & 7.5 & 32,770 & 19,943 & $-12,827$ \\
\hline 2009 & 228,769 & 7.9 & 32,115 & 18,021 & $-14,094$ \\
\hline 2010 & 229,251 & 8.4 & 31,187 & 19,307 & $-11,880$ \\
\hline 2011 & 240,432 & 9.5 & 37,241 & 22,822 & $-14,419$ \\
\hline 2012 & 241,671 & 9.1 & 35,752 & 21,872 & $-13,880$ \\
\hline 2013 & 242,879 & 10 & 40,387 & 24,355 & $-16,032$ \\
\hline 2014 & 226,641 & 11.7 & 41,323 & 26,413 & $-14,910$ \\
\hline 2015 & 206,858 & 14.2 & 39,514 & 29,363 & $-10,151$ \\
\hline 2016 & 212,595 & 13.8 & 42,016 & 29,390 & $-12,626$ \\
\hline 2017 & 217,166 & 12.1 & 41,032 & 26,198 & $-14,834$ \\
\hline 2018 & 225,545 & 12 & 44,331 & 26,990 & $-17,341$ \\
\hline
\end{tabular}

Source: calculated according to the State Statistics Service of Ukraine

low value-added products, burden the overall value of the sector (Reviron. 2018). It is obvious that if the participants of agri-food chains ignore in Ukrainian practice the issues of equivalence of exchange among agricultural producers, the desire to set fair prices for products will increase, which will have a significant impact on the reputation of processors, wholesalers and retailers and their criteria for socially responsible business in the future.

We share the view that the efficiency of agri-food chains is determined at three levels: long-term partnerships with suppliers, customer relationships and the level and quality of information exchange, and flexibility, efficiency and innovation are the main characteristics of its productivity (Puška, Kozarević and Okičić, 2019).

Inequivalence of exchange and monopoly position of processing enterprises and organizations of wholesale and retail trade forces the management of agricultural enterprises to make decisions on joining highly concentrated, vertically integrated farms of the corporate sector of the agricultural economy, which combines agriculture, processing, wholesale equivalence of intersectoral exchanges based on the introduction of transfer pricing (Sabluk and Mohylova, 2014). At the same time, we believe that the strengthening of the monopolization of agricultural production, and processing of certain types of agricultural products may pose a threat to national security.

We share the opinion that ignoring the problem of intersectoral balance, structural factors leads to distortion of price proportions, unjustified success of some industries to the detriment of others, displacement of domestic products by imports and others. The resulting structural imbalances can be transformed into persistent constraints on economic growth (Burkovskyi, 2016). At the same time, significant differences in the formation and functioning of certain types of agri-food chains require a comprehensive analysis of their balance, which will determine the role at the level of each participant in the formation of value added and equivalent exchange. Therefore, the macroeconomic analysis of equivalent exchange in agri-food chains should be supplemented by a detailed analysis at the level of a specific type of product.

The balanced functioning of agri-food chains is important for the sustainable development of all participants involved, as well as for the country's economy and the world, taking into account their social and environmental consequences. In Ukrainian practice, agri-food chains take the form of national or global chains, which require appropriate management models, in which often a vertically integrated holding company or a foreign company coordinates a network of suppliers, which affects the form and economic relations of involved participants and final products, raw materials.

In this regard, scientists believe that in order to ensure the sustainability of short agri-food chains, it is advisable to create centers for collecting scientific information, disseminating best practices and positive experiences in order to disseminate them among small producers, which will help spread knowledge and reduce transaction costs (Colantuono, 2017).

\section{Conclusions}

It is proved that unfavourable conditions for agriculture in the formation of gross value added cause the outflow of capital from the industry is constantly under the influence of violation of inequality of exchange with the food industry and trade, despite significant amounts of state support. This circumstance requires the introduction of effective tools for regulating 
the formation of gross value added of the agricultural sector, which may include antitrust measures, promotion of market infrastructure, as well as the development of agricultural cooperation and agri-industrial integration at the level of agri-food chains.

At the same time, the system of price parity regulation should become a part of the general system of regulation of the country's agricultural sector. Regulation of price parity should take into account not only the stability in the intersectoral exchange of agricultural enterprises, but also small farms, farmers, as unstable price conditions complicate the sustainable development of small farms. We believe that the achievement of intersectoral balance is not solved only by ensuring price parity as a part of the process of ensuring intersectoral exchange. To do this, it is necessary to conduct in-depth studies of the relationship of agriculture with the budget, the credit system, other sectors of the economy, the entire system of financial flows. In addition, in order to ensure a stable intersectoral balance, it is necessary to strengthen the effectiveness of existing mechanisms of state support for the agricultural sector, the use of mechanisms to regulate prices, rural development, and so on. Thus, intersectoral parity is a broader concept than price parity, as exchange parity can be ensured through the use of economic instruments of state regulation of the agricultural sector and rural areas, which will include budget financing of rural development expenditures, subsidies for research and innovation, balanced credit policies, modernization and innovative renewal of the agricultural production base, development of agricultural cooperation and direct state support for small agricultural producers.

\section{References}

ALEINIKOVA, 0. V. 2011. Price parity as a tool for state regulation and reform of agriculture. In Investments: practice and experience, 2011, no. 1, pp. 108-111.

BURKOVSKYI, P. A. 2014. Theoretical foundations of parity of economic relations in the agricultural sector of Ukraine. Collection of scientific works of Podolsk State Agrarian and Technical University. In Agricultural sciences, vol. 22, 2014, no. 2, pp. 55-60.

BURKOVSKYI, P. A. 2016. Parity of intersectoral relations in the agricultural sector: retrospective, present, future. In Food resources, 2016, no. 6, pp. 61-69.

COLANTUONO, F. - DJELVEH, S. - CONTÒ, F. 2017. Economic sustainability in Short Food Supply Chain. The case of the Horizon 2020 project "Short Food Supply Chain Knowledge and Innovation Network (SKIN). In Rivista di Studi sulla Sostenibilita, vol. 1, 2017, pp. 169-181. DOI: 10.3280/RISS2017-001011
HAHREN, F.0. 2014. Modeling of parity in economic relations between agricultural producers and processing industries. Productivity of agro-industrial production. In Economic sciences, 2014, no. 25, pp. 91-95.

HRUZDIEV, V. Yu. 2014. Theoretical approaches to the formation of parity relations in the agro-industrial complex. Productivity of agro-industrial production. In Economic sciences, 2014, no. 26, pp. 44-49.

OLIINYK, 0. V. 2015. Price parity and formation of the cost of crop production in terms of intensification of production. In Economics of agro-industrial complex, 2015.

POMARICI, E. 2018. Food Value Chains: Governance: Chapter in book: Reference Module in Food Science Models. DOI: 10.1016/B978-0-08-100596-5.22111-2

PUŠKA, A. - KOZAREVIĆ, S. - OKIČIĆ, J. 2019. Investigating and analyzing the supply chain practices and performance in agro-food industry. In International Journal of Management Science and Engineering Management, vol. 15, 2019, no. 1, pp. 9-16. DOI: 10.1080/17509653.2019.1582367

REVIRON, S. - PYTHON, P. 2018. Analysis of value distribution in the dairy sector. In Agrarforschung Schweiz, vol. 9, 2018, no. 4, pp. 134-141. https://www. researchgate.net/publication/324644184 Analysis of value distribution in the dairy sector

SABLUK, P. T. - MOHYLOVA, M.M. 2014. Price parity and agro-industrial complex as an economic basis for technical and technological re-equipment of agricultural production. Technical and technological aspects of development and testing of new equipment and technologies for agriculture of Ukraine. In Doslidnytske, vol. 18, 2014, no. 1, pp. 29-38.

VARCHENKO, I. - SVYNOUS, V. - SKOTSYK, L. - KHAKHULA, 0. 2018. Price Parity of Reconstructing Technological Supply Chain Capacity in the Agricultural Sector of Ukraine. In International Journal of Supply Chain Management, vol. 7, 2018, no. 4, pp. 397-406. no. 6. pp. 47-52.

Vasylenka N. 2013. Parity of intersectoral relations and expanded reproduction of labor potential in the agro-industrial complex. Agrarian economy. T. 6, no. 1-2. pp. 66-69.

\section{Contact address}

Olha 0. Varchenko, Bila Tserkva National Agrarian University, Faculty of Economy, Cathedral Square, 8/1, Bila Tserkva, Kyiv region, 09117, Ukraine, e-mail:1207olia@gmail.com 